\title{
Pendampingan Psikososial terhadap Perempuan Hamil di Luar Nikah*
}

\author{
Psychosocial Mentoring to Pregnant Women Out of Wedlock
}

\author{
Nirlam Septrisna Yanti Zebua ${ }^{1}$ \\ ${ }^{1}$ Program Studi S1 Teologi STT Banua Niha Keriso Protestan Sundermann \\ septrisnayanti@gmail.com
}

Received: 20 October 2021 | Revised: 29 October 2020 | Accepted: 29 October 2021 | Published online: 30 October 2021 Copyright (C) The Author(s) 2021

\begin{abstract}
This article aims to investigate how the church provides psychosocial mentoring to pregnant women out of wedlock. Taking place at the BNKP's Congregation Orahili Sifalaete, Resort 6 - every year in the congregation, there are cases of pregnancy out of wedlock. The research used the descriptive qualitative method. The data sources (participants) were fifteen people: church pastors and elders, pregnant women out of wedlock, and congregation members. The research findings show that the church has not provided psychosocial assistance to pregnant women out of wedlock. The cause of the lack of mentoring is that the church's servants do not have adequate knowledge and skills to provide psychosocial mentoring; the servant gets a rejection by the victim's case. With the lack of understanding, the servants do not dare to face the cases. At the end of the article, the author offers and recommends several concepts accompanied by implications regarding psychosocial mentoring for pregnant women out of wedlock in the congregation.
\end{abstract}

Keywords: BNKP, mentoring, pregnant women out of wedlock, psychosocial

\begin{abstract}
Abstrak
Artikel ini bertujuan untuk menyelidiki bagaimana gereja melakukan pendampingan psikososial terhadap perempuan hamil di luar nikah. Mengambil lokasi di Jemaat BNKP Orahili Sifalaete Resort 26 - di jemaat ini setiap tahunnya terdapat kasus hamil di luar nikah. Penelitian menggunakan metode penelitian deskriptifkualitatif. Sumber data (partisipan) penelitian berjumlah 15 orang, terdiri dari pendeta jemaat dan Satua Niha Keriso atau penatua, pelaku atau korban hamil di luar nikah, dan warga jemaat. Temuan penelitian menunjukan bahwa gereja belum melakukan pendampingan psikososial terhadap perempuan hamil di luar nikah. Penyebab belum terlaksananya pendampingan adalah pelayan tidak memiliki pengetahuan dan keterampilan yang memadai untuk melakukan pendampingan psikososial; pelayan mendapat penolakan dari korban atau pelaku. Akibat minimnya pemahaman tentang pendampingan ini, para pelayan tidak memiliki keberanian menghadapi kasus yang terjadi. Pada bagian akhir artikel, penulis menawarkan dan merekomendasi ulang beberapa konsep yang disertai dengan implikasi tentang pendampingan terhadap perempuan hamil di luar nikah di dalam jemaat.
\end{abstract}

Kata kunci: BNKP, pendampingan, perempuan hamil di luar nikah, psikososial

\section{Pendahuluan}

Dalam konteks jemaat saat ini, ada banyak masalah kehidupan yang dialami oleh setiap jemaat, salah satunya, perempuan hamil di luar nikah. Dari persoalan-persoalan ini, banyak korban membutuhkan pendekatan atau pendampingan dari gereja, tetapi gereja hanya memperhatikan masalah instan yang mudah dipecahkan. Kesulitan yang dialami oleh korban selalu diabaikan, dan membiarkan mereka sendiri menyelesaikan setiap masalah yang dihadapi.

Menurut Jacob Daan Engel, pendampingan merupakan proses perbuatan mendampingi sesama

*Artikel ini merupakan intisari Skripsi Nirlam Septrisna Yanti Zebua, "Pendampingan Psikososial terhadap Perempuan Hamil di Luar Nikah" (STT BNKP Sundermann, 2021). 
yang mengalami krisis dalam persoalan hidup. ${ }^{1}$ Tanpa pendampingan pada orang yang mengalami krisis maka manusia tidak bisa memberadabkan dirinya dengan sesamanya. ${ }^{2}$ Oleh sebab itu pendampingan psikososial ini dibutuhkan oleh mereka yang mengalami hamil di luar nikah. Realita yang terjadi, mereka yang mengalami hamil di luar nikah tidak diperhatikan oleh gereja dan terus menerus membiarkan korban menuntaskan sendiri masalahnya; membiarkan korban terjauhkan dari persekutuan, keluarga maupun dalam masyarakat. Akibatnya perempuan hamil di luar nikah mengalami tekanan psikologi dan sosial.

Dalam perspektif pendampingan pastoral dinyatakan bahwa gereja yang seharusnya memberikan pertolongan melalui pendampingan kepada setiap jemaat yang memiliki persoalan hidup. Dachi mencatat bahwa "tugas gereja adalah perwujudan tubuh kristus yang artinya melayani orang-orang yang butuh tempat tinggal, pembebasan, kemerdekaan bagi orang yang terhukum, kebutuhan pemeliharaan, jaminan keselamatan, keamanan dari manusia; gereja yang melakukan pelayanan yang sifatnya menghidupkan, memelihara, dan menyelamatkan umat manusia (Mat. 25:31-46); gereja ada bukan untuk kepentingan diri sendiri tetapi untuk dunia."3 Dengan demikian, perempuan yang hamil di luar nikah adalah masalah yang memerlukan pendampingan psikososial oleh gereja..

Temuan awal penulis menunjukkan bahwa mereka yang mengalami kasus hamil di luar nikah sangat membutuhkan pendampingan atau pendekatan yang dilakukan oleh gereja. Dengan harapan, agar dapat keluar dari masalah yang semakin menjerat kehidupan setiap korban, mereka mampu memperoleh pembaharuan hidup serta mampu membina sebuah keluarga. Tetapi yang menjadi persoalan adalah gereja kurang memberikan pendampingan kepada korban, karena para pelayan memiliki keterbatasan pengetahuan dan keterampilan dalam melakukan pendampingan, serta pelayan tidak terlalu yakin untuk mendekati para korban.

Di sisi lain, pelayanan yang telah dilakukan gereja terhadap korban hanya sebatas pelayanan dalam bentuk penggembalaan, mendampingi

\footnotetext{
${ }^{1}$ Jacob Daan Engel, Pastoral Dan Kebutuhan Dasar Konseling (Jakarta: BPK Gunung Mulia, 2016), 1-2.

${ }^{2}$ Totok S. Wiryasatputra, Ready to Care: Pendampingan Dan Konseling Psikologi (Yogyakarta: Galang Press, 2006), 17.
}

keluarga korban melalui persekutuan serta memberikan motivasi dan arahan oleh pendeta jemaat. Pelayanan yang telah dilakukan ini masih belum menjawab pergumulan iman jemaat yang hamil di luar nikah. Sehingga, masih terdapat korban yang memilih meninggalkan persekutuan dan menyalahkan gereja karena tidak berpihaknya gereja kepada korban.

Hasil penelitian menujukkan bahwa persoalan yang dialami oleh korban setelah mengalami kasus hamil di luar nikah yakni pertama: krisis fisik yakni kesulitan dalam persalinan, pengguguran bayi, penyakit badan, gangguan kejiwaan, relasi yang tidak harmonis dengan suami. ${ }^{4}$ Kedua, krisis mental yakni menutup diri dengan lingkungan sosialnya, penolakan dalam keluarga, gangguan psikologi, memberontak, stress, dan putus asa. Ketiga, krisis sosial yakni pengucilan dari masyarakat, tidak dianggap dalam keluarga, anak yang dikandung menjadi korban pembulian di tengah masyarakat. Keempat, krisis spritual yakni penyesalan, malu, menebus dosa, menyalahkan diri, dan menyembunyikan aib. ${ }^{5}$

Masalah lain yang ditemukan penulis adalah bahwa wanita hamil di luar nikah menjadi korban kekerasan dalam rumah tangga (KDRT). Karena ketidaksiapan dalam membangun keluarga, kedua pasangan saling menyalahkan. Akibatnya, semakin tidak peduli dengan pasangannya dan motivasi untuk memperbarui hidup (bertobat) semakin sedikit.

Pendampingan psikososial ini sangat penting diberikan kepada orang-orang yang mengalami krisis mental, fisik, spiritual, dan sosial. Tetapi masalahnya adalah ada perbedaan dalam perlakuan, para pelayan memandang masalah hamil di luar nikah ini lebih buruk daripada masalah lainnya, akibatnya pendekatan dan pendampingan terhadap korban tidak dilakukan, dan bahkan membiarkan mereka tersisih dari keluarga, masyarakat, dan agama. Perbedaan perlakukan dan pandangan ini mengakibatkan perempuan hamil di luar nikah menjadi terisolasi dari lingkungan sosial di mana mereka berada.

Beranjak dari uraian di atas, penelitian ini bertujuan untuk mendeskripsikan (1) faktor penyebab hamil di luar nikah; (2) dampak psikososial hamil di luar nikah bagi perempuan; dan

\footnotetext{
${ }^{3}$ Otoriteit Dachi, Kepemimpinan Gerejawi Dan Pelayanan Pastoral (Salatiga: Pasca Sarjana Sosiologi Agama UKSW, 2003), 40.

${ }^{4}$ Kartini Kartono, Psikologi Wanita 2 (Bandung: Mandar Maju, 2007), 70.

${ }^{5}$ Kartono, Psikologi Wanita 2.
} 
(3) pendampingan psikososial terhadap perempuan hamil di luar nikah - masing-masing dalam konteks penelitian yakni di Jemaat BNKP Orahili Sifalaete Resort 26. Hasil penelitian ini diharapkan dapat memberi manfaat bagi para pelayan gereja dalam melakukan pendampingan terhadap perempuan hamil di luar nikah.

\section{Metode}

Penelitian ini menggunakan metode penelitian kualitatif yakni sebuah metode riset yang sifatnya deskriptif, menggunakan analisis, mengacu pada data, memanfaatkan teori yang ada sebagai bahan pendukung, serta menghasilkan suatu teori. ${ }^{67}$ Mengambil lokasi di Jemaat BNKP Orahili Sifalaete Resort 26. Sumber data dan informan (partisipan) terdiri dari para pelayan (pendeta jemaat dan Satua Niha Keriso atau penatua), pelaku dan korban hamil di luar nikah serta beberapa orang warga jemaat.

Data dikumpulkan dengan menggunakan teknik wawancara semi terstruktur ${ }^{8}$ dan observasi. ${ }^{9}$ Analisis data dilakukan dengan menggunakan interactive model yang dikembangkan oleh Miles dan Huberman - yang secara umum digunakan dalam penelitian kualitatif, teknik ini mencakup tiga proses yakni: (a) pengumpulan dan kondensasi (reduksi) data; (b) penyajian data; (c) verikasi data dan/atau penarikan kesimpulan. ${ }^{10}$ Analisis data dilakukan selama penelitian berlangsung. ${ }^{112}$ Serta menggunakan pendekatan teori pendampingan dan psikososial.

\section{Hasil dan Pembahasan}

a. Faktor Penyebab Hamil di Luar Nikah di Jemaat BNKP Orahili Sifalaete

Berdasarkan hasil observasi dan wawancara, ditemukan bahwa kasus perempuan hamil di luar nikah yang terjadi kepada remaja dan pemuda di Jemaat BNKP Orahili Sifalaete Resort 26 sebanyak 6 orang [2016-2021]. Dari kelima pelayan gereja yang diwawancarai oleh penulis, diperoleh informasi bahwa faktor-faktor penyebab hamil di luar nikah kepada remaja dan pemuda yakni (1) pergaulan

\footnotetext{
${ }^{6}$ Sugiyono, Memahami Penelitian Kualitatif (Bandung: CV. Alfabeta, 2015), 16-20.

${ }^{7}$ Lexy J. Moleong, Metodologi Penelitian Kualitatif (Bandung: Remaja Rosdakarya, 2017).

${ }^{8} \mathrm{H}$ Russell Bernard and Bernard H. Russell, Research Methods in Anthropology: Qualitative and Quantitative Approaches (Walnut Creek: AltaMira Press, 2006).

${ }^{9}$ Brigitte Smit and Anthony J. Onwuegbuzie, "Observations in Qualitative Inquiry: When What You See Is Not What You See," International Journal of Qualitative Methods 17, no. 1 (December 2018).
}

bebas, (2) kekerasan dalam rumah tangga (KDRT), (3) pemikat/mantra (pelet/dunia gelap), (4) ekonomi keluarga, jujuran (böwö) yang tinggi, (5) pertumbuhan rohani - minimnya pemahaman pemuda dan remaja dalam menjaga kekudusan hidup, dan (6) perhatian dari orangtua. Keenam faktor ini menyebabkan remaja dan pemuda terjebak dalam kasus hamil di luar nikah [ $\left.\mathrm{R}_{3-7}, 23 / 3\right]$.

\begin{tabular}{lllll}
\multicolumn{5}{c}{ Subjek (Partisipan/Responden) Penelitian } \\
\hline Resp. & Nama & L/P & Status & Alamat \\
$\mathrm{R}_{1}$ & Pdt. Asal Niati Zega & $\mathrm{P}$ & Pelayan & Desa Namohalu \\
$\mathrm{R}_{2}$ & Pdt. Yaterorogo Zendrato & $\mathrm{L}$ & Pelayan & Desa Bawodesolo \\
$\mathrm{R}_{3}$ & Yuniria Zebua & $\mathrm{P}$ & Pelayan & Desa Orahili Tumori \\
$\mathrm{R}_{4}$ & Titian Hulu & $\mathrm{P}$ & Pelayan & Desa Orahili Tumori \\
$\mathrm{R}_{5}$ & Eliaso Zebua & $\mathrm{L}$ & Pelayan & Desa Orahili Tumori \\
$\mathrm{R}_{6}$ & Balazi Zebua & $\mathrm{L}$ & Pelayan & Desa Orahili Tumori \\
$\mathrm{R}_{7}$ & Elibudi Zebua & $\mathrm{L}$ & Pelayan & Desa Orahili Tumori \\
$\mathrm{R}_{8}$ & Yana Zebua & $\mathrm{P}$ & Warga Jemaat & Desa Orahili Tumori \\
$\mathrm{R}_{9}$ & Animala Zebua & $\mathrm{P}$ & Warga Jemaat & Desa Orahili Tumori \\
$\mathrm{R}_{10}$ & Responden [10] & $\mathrm{P}$ & Pelaku/Korban & Desa Orahili Tumori \\
$\mathrm{R}_{11}$ & Responden [11] & $\mathrm{P}$ & Pelaku/Korban & Desa Orahili Tumori \\
$\mathrm{R}_{12}$ & Responden [12] & $\mathrm{P}$ & Pelaku/Korban & Desa Orahili Tumori \\
$\mathrm{R}_{13}$ & Responden [13] & $\mathrm{p}$ & Pelaku/Korban & Desa Orahili Tumori \\
$\mathrm{R}_{14}$ & Responden [14] & $\mathrm{P}$ & Pelaku/Korban & Desa Orahili Tumori \\
$\mathrm{R}_{15}$ & Responden [15] & $\mathrm{P}$ & Pelaku/Korban & Desa Orahili Tumori \\
\hline & & & &
\end{tabular}

Faktor penyebab hamil di luar nikah di atas turut dibenarkan oleh pelaku atau korban. Mereka mengalami hamil di luar nikah karena kekerasan fisik yang dilakukan oleh orang tua kepada mereka $\left[\mathrm{R}_{11} \& \mathrm{R}_{12}\right]$. Lebih lanjut, dua dari enam responden (pelaku/korban) mengatakan bahwa mereka mengalami hamil di luar nikah karena pergaulan bebas (tanpa batas) dengan teman dan pasangannya, serta penyalahgunaan teknologi dan komunikasi [ $\mathrm{R}_{10}$ $\left.\& \mathrm{R}_{13}\right]$. Lainnya, faktor ekonomi keluarga $\left[\mathrm{R}_{15}\right]$ dan oleh karena persoalan jujuran yang tinggi yang diminta oleh orangtua kepada anak [ $\left.\mathrm{R}_{10-15}\right]$.

\section{b. Dampak Hamil di Luar Nikah bagi Perempuan}

Keenam responden korban kasus hamil di luar nikah $\left[\mathrm{R}_{10-15}\right]$ mengatakan bahwa dampak psikososial yang mereka alami setelah hamil di luar nikah adalah: pertama mengalami gangguan mental di

\footnotetext{
${ }^{10}$ Matthew B. Miles, A. Michael Huberman, and Johnny Saldaña, Qualitative Data Analysis: A Methods Sourcebook, 3rd ed. (New York, NY: SAGE Publications, Inc., 2014), 3133.

${ }^{11}$ John W Cresswell, Research Design: Qualitative, Quantitative, and Mixed Methods Approaches, Research Design, Second Edition, 4th ed. (SAGE Publications, Inc., 2014).

${ }^{12}$ Burhan Bungin, Penelitian Kualitatif: Komunikasi, Ekonomi, Kebijakan Publik, Dan Ilmu Sosial Lainnya, Jakarta. (Kencana Prenada Media Group, 2011).
} 
antaranya depresi, tertekan batin dalam keluarga dan masyarakat, malu, menyesal, rendah diri, pemberontakan dalam diri, merasa berdosa, dan kehilangan masa depan; mendapat penolakan dari keluarga (dikutuk oleh orang tua dan tidak diterima sebagai anak). Kedua, mengalami kekerasan fisik dari orang tua dan dari keluarga barunya (pasangan). Ketiga, mengalami gangguan kesehatan berkepanjangan, dua dari enam responeen mengaku telah melakukan aborsi (pengguguran), namun tidak berhasil.

Keempat, masalah spritual yakni penyesalan, menjauhkan diri dari persekutuan, serta malu terhadap diri sendiri dan juga kepada Tuhan, suami melarang untuk beribadah. Kelima, tekanan sosial yakni mereka susah berinteraksi dengan lingkungan sosialnya karena sering mengalami perilaku buruk yang terus-menerus (bullying) dari masyarakat, tidak mendapat hak warisan dalam keluarga, mendapatkan pengucilan dari jemaat atau gereja, serta tidak diresmikan secara adat sesuai dengan kebudayaan Nias.

\section{c. Pendampingan Psikososial Gereja terhadap Perempuan Hamil di Luar Nikah}

Berdasarkan hasil wawancara dengan para pelayan diperoleh informasi bahwa pelayan gereja tidak pernah melaksanakan pendampingan terhadap keenam korban yang hamil di luar nikah, kecuali penggembalaan. Empat dari enam responden dalam kapasitas sebagai pelayan, mengatakan tidak memiliki pengalaman atau pengetahuan melakukan pendampingan terhadap korban sehingga program pendampingan belum diprogramkan oleh jemaat. Menurut pendeta jemaat, alasan belum terlaksananya pendampingan terhadap korban karena pendeta jemaat sebelumnya tidak pernah memberikan pemahaman kepada para pelayan (SNK/Penatua) tentang tugas pendampingan, selain penggembalaan $\left[\mathrm{R}_{1}\right]$. Sementara, dalam peraturan BNKP dijelaskan bahwa, kepada setiap jemaat yang mengalami persoalan hidup termasuk bagi jemaat yang mengalami hamil di luar nikah menjadi tugas pelayan untuk mendampingi. Namun, realita pelayan tidak berani mengambil resiko untuk terlibat menyelesaikan setiap kasus yang terjadi, dengan alasan (kuatir) ditolak oleh keluarga dan korban yang masih belum siap menerima pendampingan secara khusus. Dari data dan informasi yang terkumpul, penulis menyimpulkan bahwa pendampingan psiksososial terhadap perempuan hamil di luar nikah

${ }^{13}$ Lembaga Baptis Literatur, Pola Hidup Kristen (Malang: BPK Gunung Mulia, 2002), 55-60. di Jemaat BNKP Orahili Sifalaete belum menjadi program pelayanan jemaat. Pendampingan psikososial terhadap perempuan hamil di luar nikah belum memenuhi kebutuhan para korban, ada pandangan - kasus ini adalah masalah biasa di tengah-tengah jemaat dan dapat tidak dipedulikan.

Akibat tidak efektifnya pelaksanaan pendampingan psikososial terhadap korban hamil di luar nikah ini, mendorong setiap korban menyelesaikan sendiri masalahnya, menjauhkan diri dari persekutuan, mengalami tekanan psikis dan sosial berkepanjangan, menjadi korban kekerasan dalam keluarga serta ketidaksiapan pasangan dalam membangun keluarga yang baru. Enam responden korban kasus hamil di luar nikah, secara tegas menyatakan bila mereka sangat mengharapkan peran gereja memberi perhatian dan mendampingi mereka selain penggembalaan itu sendiri. Masalah hamil di luar nikah merupakan penyimpangan seksualitas yang sulit untuk diterima karena melibatkan bagian hidup perempuan yang sangat pribadi dan erat hubungan dengan keberadaan kita, perempuan yang hamil di luar nikah menunjukan penghinaan yang kejam, merendahkan manusia, bahkan menurunkan martabat manusia. ${ }^{13}$ Perempuan yang telah hamil di luar nikah susah diterima dan dianggap buruk dalam masyarakat, keluarga, dan bahkan agama; sehingga korban sulit keluar dari persoalan yang dialaminya.

Faktor-faktor penyebab hamil di luar nikah sebagaimana dijelaskan di atas sejalan dengan teori atau hasil penelitian sebelumnya yakni "kurangnya informasi tentang seks (pengetahuan), pergaulan bebas, norma agama, pengetahuan seksualitas, pembentengan/pertahanan diri, perkembangan teknologi." 14

Dampak buruk hamil di luar nikah yang terjadi kepada remaja dan pemuda di Jemaat BNKP Orahili Sifalaete, seperti ketertekanan batin, penganiayaan oleh orang tua, tidak dianggap sebagai anak dalam keluarga, dan dikutuk oleh orang tua serta dijauhkan dalam adat istiadat Nias - bertentangan dengan kewajiban dan tanggung jawab orang tua dalam masa-masa krisis remaja. Menurut penulis orang tua tidak perlu menjauhkan dan membiarkan seorang anak menyelesaikan masalahnya sendiri, karena tanggung jawab orang tua sangat besar terhadap perkembangan psikologi remaja menuju kedewasaan Surbakti menjelaskan bahwa kewajiban dan tanggung jawab orang tua sangatlah penting dalam masa-masa krisis remaja, di antaranya pertama bertindak sebagai teman diskusi yang

${ }^{14}$ Sarlito Wirawan Sarwono, Psikologi Remaja, Revisi. (Jakarta: Rajawali Pers, 2010), 60-80. 
menyenangkan. Kedua menghindari sikap menyalahkan dan menghakimi. Ketiga jangan melecehkan sikap psikologi mereka yang labil. Keempat menghindari hukuman yang dapat membuat perasaan terluka. ${ }^{15}$

Permasalahan yang dihadapi oleh setiap orang dalam kasusnya, dalam hal ini remaja dan pemuda yang hamil di luar nikah mengalami berbagai dampak psikososial, yakni masalah fisik, mental, spritual, dan sosial. Krisis ini bisa ditemukan dalam persoalan fisik yang diakibatkan oleh masalah psikologis. Sehingga menimbulkan penderitaan, keprihatinan, gangguan, konflik, ketidaknyamanan batin, kesedihan yang dialami oleh seseorang, penyesalan, dan kurangnya pendekatan dalam beriman. ${ }^{16}$

Temuan penelitian di atas menunjukan bahwa mereka sangat sulit menuntaskan persoalan yang mereka hadapi karena bebagai tekanan dari masyarakat maupun dari dalam jemaat; dan karena alasan itulah, mereka sangat membutuhkan pendampingan dan pendekatan yang "mendamaikan dan memperbaiki hubungan" 17 dari gereja. Namun realita, gereja hanya melakukan pendampingan terhadap keluarga dari para pelaku/korban dalam bentuk kebaktian dan perkunjungan oleh pendeta jemaat, dengan tujuan agar keluarga dapat menerima semua persoalan yang terjadi pada anaknya.

Objek utama pendampingan ini adalah gereja; Dachi dalam bukunya Kepemimpinan Gerejawi dan Pelayanan Pastoral menjelaskan bahwa gereja merupakan perwujudan tubuh Kristus di dunia. Karena itu kehadiran gereja harus diperhatikan melalui sikap yang menyatakan kasih kepada sesama di dunia ini. Artinya mereka melayani orang-orang yang butuh tempat tinggal, pembebasan, kemerdekaan bagi orang yang terhukum, kebutuhan pemeliharaan dan jaminan keselamatan dan keamanan dari manusia. Hal tersebut yang mendorong gereja melakukan pelayanan yang sifatnya menghidupkan, memelihara, dan menyelamatkan umat manusia (Mat. 25:31-46). Gereja ada bukan untuk dirinya sendiri melainkan untuk dunia. ${ }^{18}$

Pendampingan yang dilakukan gereja selama ini terhadap korban masih belum sepenuhnya

${ }^{15}$ Elisa B. Surbakti, Konseling Praktis "Mengatasi Berbagai Masalah” (Bandung: Kalam Hidup, 2008), 293.

${ }^{16}$ B. Yakub Susabda, Konseling Pastoral Jilid 2 (Malang: Gandum Mas, 2000), 50.

${ }^{17}$ Aart Van Beek, Pendampingan Pastoral, ed. Rika Uli Napitupulu-Simarangkir, 4th ed. (Jakatra: Gunung Mulia, 2011), 13-16. menjawab pergumulan mereka dalam menghadapi setiap persoalan yang terjadi. Mereka mengharapkan keadilan dan kepedulian gereja agar mereka bisa mengenal kehidupan yang baru melalui pertobatan dan mampu menerima masa lalu yang pernah dilalui. Saputra mengatakan, bahwa berubah menuju pertumbuhan melalui pendampingan yang dinyatakan secara berkesinambungan dan mampu memfasilitasi orang yang didampingi menjadi agen perubahan bagi dirinya dan lingkungannya. ${ }^{19}$

Berangkat dari kealpaan pelayan dalam melakukan pendampingan psikososial terhadap perempuan hamil di luar nikah dalam konteks penelitian, Zwingli dalam Clinebell mengatakan bahwa pendampingan psikososial adalah penting dan harus didasarkan pada perspektif inkarnasi Allah dalam pribadi dan karya Yesus Kristus. Inkarnasi menggambarkan karakater Allah, yakni mengasihi, menertibkan, menciptakan, menghidupkan, menyelamatkan, memedulikan, memperhatikan, merawat, mendampingi, mengubah, menumbuhkan, mengampuni, dan sebagainya. ${ }^{20}$ Karena itu, persoalan yang dihadapi oleh perempuan hamil di luar nikah, perlu dsrespon oleh gereja melalui proses pendampingan psikososial agar dapat menjadi baru di hadapan Kristus.

Dari pembahasan di atas, hal utama yang perlu dilakukan adalah perubahan dan tanggung jawab seorang pelayan gereja kepada jemaat yang sudah terjauhkan dari Kristus. Karena itu, melalui tulisan ini - penulis menyarankan dan merekomendasi ulang hal-hal berikut sebagai masukan bagi para pelayan dalam melakukan pendampingan kepada perempuan yang hamil di luar nikah.

- Mejelis jemaat perlu memasukkan kegiatan kegiatan pendampingan kepada perempuan hamil di luar nikah dalam program pelayanan jemaat BNKP Orahili Sifalaete. Pedoman pelaksanaan pendampingan juga perlu disiapkan agar pelayan lain dapat memperoleh pengetahuan dan keterampilan melakukan pendekatan dan pendampingan.

- Pendeta jemaat perlu melibatkan pelayan lain (SNK/Penatua) bahkan warga jemaat yang berpotensi dalam melaksanakan layanan

${ }^{18}$ Dachi, Kepemimpinan Gerejawi Dan Pelayanan Pastoral, 20.

${ }^{19}$ Wiryasatputra, Ready to Care: Pendampingan Dan Konseling Psikologi.

${ }^{20}$ Howard Clinebel, Tipe-Tipe Dasar Pendampingan Dan Konseling Pastoral (Jakarta: BPK Gunung Mulia, 2002), 60-75. 
pendampingan bagi perempuan hamil di luar nikah.

- Pelayan harus mengambil risiko dan kreatif menemukan alternatif pemecahan masalah yang timbul, utamanya dalam mendekati keluarga dari korban hamil di luar nikah, sehingga korban tidak semakin terkucilkan dari lingkungan sosialnya.

- Memperkenalkan Yesus Kristus. Jika salah satu pasangan belum menerima Yesus Kristus secara pribadi, maka melalui cara ini jemaat mengundang mereka untuk menerima Yesus Kristus dan agar keluarga yang akan dibangun didasarkan atas iman kepada Yesus Kristus.

- Memberikan pemahaman bahwa perkawinan bukan paksaan, karena ada tekanan atau karena telah terjadi kehamilan, tetapi mereka harus menerima tanggung jawab yang lebih besar atas siapa dirinya, menerima perasaan-perasaan sendiri, menghindari tindakan menyalahkan lingkungan dan orang lain atas keadaan dirinya, dan menyadari bahwa kedua pasangan tersebut bertangung jawab dalam keluarga barunya. ${ }^{21}$

- Melaksanakan konseling pranikah. Setiap jemaat yang ingin mendapatkan pelayanan pemberkatan nikah kudus atau peneguhan pemberkatan akan melewati pendampingan. Tujuannya untuk mempersiapkan pernikahan seumur yang akan dijalani.

- Mendampingi pasca peneguhan perkawinan. Setelah peneguhan perkawinan, pasangan tetap mendapat pendampingan yang berguna dalam kedewasaan guna memahami penerapan dalam rumah tangga yang baru tersebut serta belajar menyelesaikan masalah-masalah yang timbul. ${ }^{22}$

- Menyegarkan pikiran, mencakup personalitas seseorang yang sebagian dipakai untuk berpikir, merasakan, mengalami, memimpikan dan menciptakan.

- Membebaskan hubungan dengan lingkungan hidup untuk mempererat pemeliharaan terhadap lingkungan. Seseorang akan merasa utuh baik secara fisik, mental dan spiritual, apabila mereka ditolong untuk mengembangkan dan menghargai suatu interaksi yang bersifat memelihara.

- Menumbuhkan hubungan dengan lembagalembaga yang penting dalam hidup. Dalam suatu lembaga harus saling menyokong antara satu dengan yang lainnya karena sangat sensitif

${ }^{21}$ Gerald Corey and E. Koswara, Teori Dan Praktek Konseling \& Psikoterapi, 7th ed. (Bandung: Refika Aditama, 2013).

${ }^{22}$ John F. Mac Arthur and Wayne A. Mack, Pengantar Konseling Alkitabiah (Malang: Gandum Mas, 2002). dengan ketidakadilan, kekerasan, dan seterusnya. $^{23}$

- Mendamaikan atau memperbaiki hubungan. Salah satu kebutuhan manusia untuk hidup dan merasa aman adalah adanya hubungan yang baik dengan sesama dan lingkungannya, karena manusia merupakan sosial. Apabila hubungan tersebut terganggu, maka terjadilah penderitaan yang berpengaruh pada masalah psikososialnya. Maka pendampingan berfungsi sebagai perantara untuk memperbaiki hubungan yang rusak dan yang telah terganggu. Oleh karena itu, pendampingan dapat menjadi cermin dalam memperbaiki hubungan yang didampingi dengan sesamanya dan juga lingkungan.

- Menyembuhkan. Fungsi menyembuhkan penting dalam melakukan pendampingan, karena dapat mengarahkan seseorang dalam mengatasi kerusakan yang dialaminya. Melalui fungsi menyembuhkan yang berisi kasih sayang, rela mendengarkan segala keluhan batin dan kepedulian yang tinggi dapat membuat seseorang mengalami rasa aman dalam dirinya. Demikian juga dalam pendampingan psikososial, seseorang yang mengalami tekanan batin, terluka secara fisik dan mental membutuhkan fungsi ini dalam membantu, menyembuhkan dan mengutuhkan seseorang secara penuh.

- Mengutuhkan. Fungsi ini adalah fungsi utama karena sekaligus merupakan tujuan utama dari pendampingan pastoral yaitu pengutuhan kehidupan manusia dalam segala aspek kehidupannya yakni fisik, sosial, mental, dan spritual. $^{24}$

- Membimbing, adalah penting dalam kegiatan menolong dan mendampingi seseorang. Sebab fungsi membimbing merupakan fungsi dari pendampingan itu sendiri. Orang yang didampingi, ditolong untuk memilih dan mengambil keputusan tentang apa yang akan ditempuh atau apa yang akan menjadi masa depannya. Pengambilan keputusan tentang masa depan ataupun mengubah dan memperbaiki tingkah laku tertentu atau kebiasaan tertentu, tetap ditangan orang yang didampingi (penderita) dan itu dapat mempengaruhi keadaan jiwa. Oleh karena itu, si pendamping merupakan fasilitator terhadap yang didampingi.

\footnotetext{
${ }^{23}$ Elisabet Ditya Palupi, "Kajian Pemuda Yang Hamil Di Luar Nikah Di GKJW Jemaat Tulungrejo Dari Perspektif Pendampingan Dan Konseling Pastoral Howard Clinebell" (Universitas Kristen Satya Wacana, 2019).

${ }^{24}$ Beek, Pendampingan Pastoral.
} 
Secara umum perempuan hamil di luar nikah dikatakan sebagai pasangan yang telah melakukan penyimpangan seksualitas sebelum menikah dan dianggap sebagai pasangan yang telah berdosa dihadapan kristus. Seperti halnya dalam surat roma Roma 3:23-24 "Karena semua orang telah berbuat dosa dan telah kehilangan kemuliaan Allah, dan oleh kasih karunia telah dibenarkan dengan cumacuma karena penebusan dalam Kristus Yesus." Dalam hal ini paulus memaparkan tentang orang Yahudi maupun bukan Yahudi yang perlu memperbaiki hubungannya dengan Allah, sebab mereka berada dalam kekuasaan dosa. Hubungan manusia dengan Allah menjadi baik, kalau manusia percaya kepada Yesus. Kemudian Paulus juga menguraikan tentang hidup baru yang dialami oleh manusia. Hidup baru tumbuh karena adanya hubungan yang baru dengan Allah, orang yang sudah percaya dengan Yesus, hidup damai dengan Allah dan Roh Allah akan membebaskan dia dari dosa dan kematian.

Demikian halnya, ketika diperhadapkan dengan korban hamil di luar nikah di Jemaat BNKP Orahili Sifalaete. Korban tidak seharusnya dikucilkan, dikutuk, tidak dianggap anak lagi oleh keluarga, begitu juga masyarakat tidak perlu mengahakimi karena manusia di dunia ini tidak ada yang benar dan semuanya telah berbuat dosa di hadapan Tuhan. Oleh sebab itu, gereja yang seharusnya melakukan perdamaian antara korban, keluarga, maupun masyarakat, bukan menjauhkan atau membiarkan korban menyelesaikan masalah secara individual. Gereja seharusnya menolong, membimbing, menopang, mengarahkan, memperbaiki hubungan manusia dengan Tuhan. Agar korban dapat melakukan pertobatan dan bisa menerima Kristus dalam kehidupan mereka.

Yoh. 15:12 "Inilah perintah-Ku, yaitu supaya kamu mengasihi, seperti aku telah mengasihi kamu." Dalam teks ini, Yohanes memamparkan tentang Yesus yang mengasihi murid-Nya yang bernama Yohanes, melalui teks ini Yohanes menunjukan tentang kemanusiaan-Nya di dalam dunia dalam mengasihi manusia. Oleh sebab itu, gereja yang menjadi objek utama dalam mengasihi, memmerhatikan, dan menolong mereka yang sudah terjauhkan dari keluarga dan di dalam persekutuan. Dalam hal ini gereja menjadi alat oleh Kristus dalam menolong manusia yang sudah terjauhkan dari-Nya dan mengeluarkan mereka dari masa lalu menuju terang melalui Kristus. Dan, karena itu masyarakat sadar akan sifat mereka yang merendahkan dan menghakimi sesama manusia yang telah malakukan dosa. Dari kesadaran itu menjadikan mereka peduli, mengasihi, dan merangkul korban yang sudah tersisihkan dari jemaat, dengan mengasihi mereka. Sehingga korban tidak mengalami ketertekanan batin di dalam kehidupannya melainkan dengan perhatian dari masyarakat, keluarga maupun gereja masalah akan dapat teratasi.

\section{Kesimpulan}

Bertolak dari penelitian diatas, pendampingan psikososial terhadap perempuan hamil di luar nikah masih belum sepenuhnya menjawab pergumulan setiap jemaat terutama yang mengalami kasus hamil di luar nikah di jemaat BNKP Orahili Sifalaete Resort 26. Akibat dari hal itu ada banyak keluarga yang menjauhkan diri dari berbagai persekutuan karena tekanan dari masyarakat, maupun dalam jemaat. Remaja dan pemuda yang telah terlibat dalam kasus hamil di luar nikah kebanyakan dari mereka mengalami krisis psikososial dalam kehidupannya sehingga menjadikan setiap individu menutup diri dan takut beradaptasi dengan lingkunganya. Kasus perempuan hamil di luar nikah diakibatkan karena faktor dari dalam diri, keluarga, dan lingkungan. Sehingga dampaknya mengakibatkan rusaknya masa depan, hubungan anak dengan orangtua, serta menjadi korban kekerasan dalam rumah tangga.

Akibat dari kurangnya kepedulian gereja terhadap remaja dan pemuda, maka mengakibatkan setiap tahun bertambahnya kasus hamil di luar nikah. Seharusnya dalam hal ini orangtua harus memberikan perhatian lebih terhadap setiap anak yang menuju dewasa dan memantau setiap kegiatan yang dilakukan oleh seorang anak. Orangtua dalam hal ini mempunyai tanggung jawab yang besar terhadap setiap anak jika orang tua terus memberikan tekanan buruk dalam keluarga maka persoalan kasus hamil di luar nikah tidak akan mudah terselesaikan dengan baik dan korban akan terus mengalami pembulian dari masyarakat.

Dalam setiap persoalan yang telah terjadi gereja belum melakukan pendampingan psikososial terhadap setiap korban karena keterbatasan dalam pengetahuan setiap pelayan yang masih belum memahami pendampingan secara khusus kepada korban yang mengalami kasus hamil di luar nikah. Kebanyakan yang terjadi di Jemaat BNKP Orahili Sifalaete Resort 26 membiarkan setiap korban menuntaskan sendiri masalahnya, sehingga korban terus menjauhkan diri dari berbagai persekutuan dan menyalahkan ketidakadilan gereja terhadap mereka. Oleh sebab itu, seharusnya seluruh Majelis Jemaat BNKP Orahili Sifalaete dapat memprogramkan 
pelayanan melalui pendampingan secara khusus terhadap perempuan hamil di luar nikah serta keluarga baru dibekali dengan berbagai pembaruan hidup dalam menuju pertobatan kepada Kristus serta mampu bertahan dalam berbagai persoalan yang terjadi dalam keluarga baru.

\section{Ucapan Terima Kasih}

Peneitian ini tentunya akan sulit diselesaikan tanpa dukungan dari berbagai pihak. Karena itu, pada kesempatan ini penulis menyampaikan terimakasih yang sedalam dalamnya kepada Pendeta Jemaat BNKP Orahili Sifalaete Resort 26. Dan juga kepada setiap jemaat yang telah menjadi narasumber bagi penulis dalam menyampaikan setiap persoalan yang dihadapi dalam jemaat. Mereka telah mendukung penelitian ini dalam bentuk penyediaan dan pengumpulan data.

\section{Referensi}

Mac Arthur, John F., and Wayne A. Mack. Pengantar Konseling Alkitabiah. Malang: Gandum Mas, 2002.

Beek, Aart van. Pendampingan Pastoral. Edited by Rika Uli Napitupulu-Simarangkir. 4th ed. Jakatra: BPK Gunung Mulia, 2011.

Bungin, Burhan. Penelitian Kualitatif: Komunikasi, Ekonomi, Kebijakan Publik, Dan Ilmu Sosial Lainnya. Jakarta. Kencana Prenada Media Group, 2011.

Clinebel, Howard. Tipe-Tipe Dasar Pendampingan Dan Konseling Pastoral. Jakarta: BPK Gunung Mulia, 2002.

Corey, Gerald, and E. Koswara. Teori Dan Praktek Konseling \& Psikoterapi. 7th ed. Bandung: Refika Aditama, 2013.

Cresswell, John W. Research Design: Qualitative, Quantitative, and Mixed Methods Approaches. Research Design, Second Edition. 4th ed. SAGE Publications, Inc., 2014.

Dachi, Otoriteit. Kepemimpinan Gerejawi Dan Pelayanan Pastoral. Salatiga: Pasca Sarjana Sosiologi Agama UKSW, 2003.

Engel, Jacob Daan. Pastoral Dan Kebutuhan Dasar Konseling. Jakarta: BPK Gunung Mulia, 2016.

Kartono, Kartini. Psikologi Wanita 2. Bandung: Mandar Maju, 2007.

Lovelace, Richard. Pola Hidup Kristen. Malang: Gandum Mas, 2002.

Miles, Matthew B., A. Michael Huberman, and Johnny Saldaña. Qualitative Data Analysis: A Methods Sourcebook. 3rd ed. New York, NY: SAGE Publications, Inc., 2014.

Moleong, Lexy J. Metodologi Penelitian Kualitatif. Bandung: Remaja Rosdakarya, 2017.

Palupi, Elisabet Ditya. "Kajian Pemuda Yang Hamil Di Luar Nikah Di GKJW Jemaat Tulungrejo Dari
Perspektif Pendampingan Dan Konseling Pastoral Howard Clinebell." Universitas Kristen Satya Wacana, 2019.

Russell, H Russell Bernard and Bernard H. Research Methods in Anthropology: Qualitative and Quantitative Approaches. Walnut Creek: AltaMira Press, 2006.

Sarwono, Sarlito Wirawan. Psikologi Remaja. Revisi. Jakarta: Rajawali Pers, 2010.

Smit, Brigitte, and Anthony J. Onwuegbuzie. "Observations in Qualitative Inquiry: When What You See Is Not What You See.” International Journal of Qualitative Methods 17, no. 1 (December 2018).

Sugiyono. Memahami Penelitian Kualitatif. Bandung: CV. Alfabeta, 2015.

Surbakti, Elisa B. Konseling Praktis "Mengatasi Berbagai Masalah.” Bandung: Kalam Hidup, 2008.

Susabda, Yakub B. Konseling Pastoral II. Malang: Gandum Mas, 1996.

Wiryasatputra, Totok S. Ready to Care: Pendampingan Dan Konseling Psikologi. Yogyakarta: Galang Press, 2006. 